\title{
Agenda-setting in public policies: the strategy for financial education in Brazil through the lens of the multiple streams model
}

CRistina TAUAF Ribeiro ${ }^{1}$

${ }^{1}$ FundaçÃo Getulio Vargas (FGV EAESP) / Escola de Administração de EMPresas de SÃo Paulo, SÃo Paulo - SP, Brasil

\begin{abstract}
This article analyzes how the National Financial Education Strategy was established in Brazil. This case study on the agenda-setting and policy formulation in the field of public policies is based on John Kingdon's multiple streams model. It aims to contribute to the understanding of government decision-making processes by identifying theoretical elements in an empirical situation. Since the early 2000s, financial inclusion is considered by international organizations and governments as a way of fighting poverty. This culminated in the G20's Principles for Innovative Financial Inclusion, launched in 2010. However, the perception that the population's financial education is important for social inclusion was disseminated years earlier by the Organization for Economic Co-operation and Development (OECD). Since 2003, this organization has actively developed content and recommendations for the adoption of financial education strategies by countries. In Brazil, the topic gained space in the government agenda in 2007 and was a permanent public policy by December 2010. Based on bibliographical and documentary research methods, this study demonstrates that the influence exerted by the OECD was not sufficient to raise immediate government attention to the topic and points to a more complex set of factors and actors that allow the coupling of the three streams, resulting in the escalation of the topic to the decision agenda.
\end{abstract}

Keywords: Financial education. Agenda. Streams.

\section{Agenda-setting in public policies: the strategy for financial education in Brazil through the lens of the multiple streams model}

\section{Resumo}

Este artigo analisa a trajetória que levou ao estabelecimento da Estratégia Nacional de Educação Financeira (ENEF) no Brasil. Trata-se de estudo de caso sobre agenda e formulação no campo das políticas públicas e, ao se apoiar no modelo de múltiplos fluxos (MMF) de John Kingdon, identifica elementos teóricos em uma situação de caráter empírico, objetivando contribuir para o entendimento dos processos decisórios no âmbito estatal. Desde o início dos anos 2000, a inclusão financeira passou a ser vista por organismos internacionais e governos como uma frente de combate à pobreza, culminando com o lançamento, em 2010, dos Princípios para Inclusão Financeira Inovadora do Grupo dos 20 (G20). No entanto, a percepção de que a educação financeira da população é importante para a inclusão social começou a ser disseminada anos antes, pela Organização para Cooperação e Desenvolvimento Econômico (OCDE). A partir de 2003, esse órgão desenvolveu ativamente conteúdos e recomendações para a adoção de estratégias de educação financeira pelos países. No Brasil, o tema começou a ganhar corpo na agenda governamental em 2007 e tornou-se uma política pública de caráter permanente em dezembro de 2010. Calcado em pesquisa bibliográfica e documental, este estudo demonstra que a influência exercida pela OCDE não foi suficiente para despertar a atenção imediata do governo e aponta um conjunto mais complexo de fatores e atores que, orquestrados, propiciaram a convergência de fluxos que resultou na ascensão do tema à agenda de decisões.

Palavras-chave: Educação financeira. Agenda. Fluxos.

\section{Agenda en políticas públicas: la estrategia de educación financiera en Brasil a la luz del modelo de corrientes múltiples}

\section{Resumen}

Este artículo analiza la trayectoria que condujo al establecimiento de la Estrategia Nacional de Educación Financiera en Brasil. Es un estudio de caso sobre agenda y formulación en políticas públicas y, al apoyarse en el modelo de corrientes múltiples de John Kingdon, identifica elementos teóricos en una situación empírica, con el objetivo de contribuir a la comprensión de los procesos decisorios públicos. Desde principios de los años 2000, los organismos internacionales y gobiernos consideran la inclusión financiera como un modo de combate a la pobreza, destacándose el lanzamiento de los Principios para la Inclusión Financiera Innovadora del G20, en 2010. Sin embargo, la percepción de que la educación financiera de la población es importante para la inclusión social comenzó a ser diseminada años antes por la Organización para la Cooperación y el Desarrollo Económico (OCDE). A partir de 2003, ese organismo desarrolló activamente contenidos y recomendaciones para la adopción de estrategias de educación financiera por parte de los países. En Brasil, el tema comenzó a crecer en la agenda gubernamental en 2007, tornándose una política pública de carácter permanente en diciembre de 2010. Basado en investigación bibliográfica y documental, este estudio demuestra que la influencia ejercida por la OCDE no fue suficiente para atraer la atención inmediata del gobierno y señala un conjunto más complejo de factores y actores que, organizados, propiciaron la convergencia de corrientes que resultó en el ascenso del tema a la agenda de decisiones del gobierno.

Palabras clave: Educación financiera. Agenda. Corrientes. 


\section{INTRODUCTION}

Financial inclusion grew in importance in the 2000s, when international organizations and governments began to shed light on it as a good way to fight poverty. Although the trend attracted more attention with the launch of the Group of 20 (G20) Principles for Innovative Financial Inclusion in 2010, the Organization for Economic Cooperation and Development (OECD) was advocating its perception that the financial education would be an essential condition for a successful process of inclusion since 2003. The OECD actively developed content, offered and disseminated recommendations for countries to adopt national financial education strategies. In Brazil, the topic started to have the attention of the government in 2007, becoming a permanent public policy ${ }_{1}$ in December 2010. As financial education is not usually in the government's top priorities list, one may wonder what were conditions and driving factors that stressed the subject to the point of it being framed as specific policy, the National Strategy for Financial Education (ENEF)?

In the matter of public policy, agenda is defined as a list of topics considered priority by a government, to which it dedicates itself. The process of agenda-setting is fundamental because a myriad of actors seek to include topics of their interest in it, aiming for these issues to become the object of governmental action. The fierce dispute for defining priorities can make a difference to what will or will not turn into concrete public policy. The study of the agenda-setting process seeks not only to answer how does a specific issue become relevant to the government and is added to the agenda at a given moment but also why only a few cases spring into governmental action. Capella (2007, p. 121) argues that "the way problems are conceptualized in the policy formulation process and the ways in which alternatives are presented and selected are fundamental issues for understanding the dynamics of State action".

Combining theoretical concepts and empirical situations, this article aims to contribute to the understanding of pre-decision processes within the State. In methodological terms, qualitative analysis is the base of this case study and bibliographic research on theories of agenda-setting and formulation in public policies supports it. In addition, documentary research was used for contextual construction, mainly OECD and ENEF information and publications, and Kingdon's (1995) theoreticalmethodological model was applied.

In addition to this introduction, the text is organized in four sections. First, a brief literature review on the theory of agendasetting focusing on the multiple streams model (MSM) is carried out. The second section presents preparatory studies for the formulation of ENEF and the general lines of the master plan. In the third section, with the purpose of identifying the elements of Kingdon's theory (1995) in the pre-decision processes of ENEF, the analysis is developed. Final considerations summarize research findings and offer suggestions for the development of future studies.

\section{Agenda-setting in public policy - a brief review of literature}

In the public policies literature, two theoretical models to explain how government agendas are set and how alternatives are presented to policy makers stand out. They are the MSM, Kingdon (1995), and the punctuated equilibrium model (PEM), Baumgartner and Jones (1993). According to Capella (2007, p. 120), these two models seek to distance the process of formulating policies, which is closer to the field of ideas, argumentation and discussion, from formal problem-solving techniques.

What mainly differs these very similar frameworks is the relevance they attribute to the media and to interest groups, as highlighted by Capella (2007, p. 116-120). While PEM considers that the media guides the attention of individuals, being fundamental in the process of agenda formation, in MSM the media only portrays issues that have already been present in the agenda, not influencing their formation. Regarding interest groups, PEM emphasizes that they play a crucial role in defining issues on the agenda, while MSM portrays these actors as more prone to blocking issues than putting them on the agenda. In the case study presented below, the application of MSM was chosen since insufficient empirical evidence on the treatment of the topic by the media was found before it culminated in government action. A similar situation was faced regarding the prominence of specific interest groups acting to influence public opinion to force the issue into the government's agenda or

\footnotetext{
${ }^{1}$ For the purposes of this article, public policy of permanent character is an expression consisting in the sense of permanence, that means, it does not present a scenario of discontinuity.
} 
its subsequent rise to the decision agenda. Other reasons that proved the model relevant for the analysis are the following: a) its conceptual elements facilitate the identification of the role played by different categories of actors and contexts in the pre-decision dynamics; b) it is characterized by the top-down choice of topics on the agenda; and c) it considers intersectoral interaction in the specification of alternatives.

Kingdon (1995) originally applied MSM to analyze the process of agenda-setting in federal health and transport policies in the United States of America (USA). Since then, countless authors applied it for analyzing national, international and local policies for different countries and sectors. A meta-analysis carried out by Jones, Peterson, Pierce et al. (2016) reported that 311 articles applying MSM concepts were published in English from 2000 to 2013. In the last two decades, Kingdon's matrix (1995) has also served as a theoretical lens for further studies on agenda-setting in public policies in Brazil. Capella (2008), Pereira and Teixeira (2011) and Nagem and Silva (2013) showed that there is common ground in many national public policies that emerged from the confluence of social, political and economic forces even when actors, content, periods and contexts are totally different. To give support to the analysis below, this section is devoted to a conceptual approach of the MSM.

Kingdon's model (1995) derives from a combination of the rational policy cycle model and the garbage can model ${ }_{2}$. For the author,

[...] in a very simplified way, we can consider that the formulation of public policies is a set of processes, including at least: 1 ) the establishment of an agenda; 2 ) the specification of the alternatives from which the choices are made; 3 ) a final choice among these specific alternatives, through a vote in the Legislative or presidential decision; and 4) the implementation of this decision (KINGDON, 2006a, p. 221).

The theory focuses on steps 1 and 2, defined as "pre-decision processes" (KINGDON, 2006b, p. 225). In these, the influences that lead to a final choice are determined by active participants (governmental and non-governmental) and processes by which agenda items and alternatives gain prominence (PINTO, 2008, p. 15).

Kingdon ranks three levels of agenda. The systemic agenda is the list of issues of concern to the country, although the government would still not give it specific attention (VIANA, 1996). The governmental agendas are "the lists of themes that are the target of serious attention by government officials". Finally, the decision agenda is "the list of topics that are subject to deliberation" (KINGDON, 2006b, p. 234).

To explain why an issue becomes the center of attention to public policy makers and how it migrates from the governmental agenda to the decision-making agenda, Kingdon (1995) characterizes government as an organized anarchy, in which 3 decision-making streams follow independent courses of action. These 3 streams are: problems, solutions or public policies (alternatives) and politics.

The problem stream relates to the means by which governmental actors become aware of situations and to the way in which these situations are defined as problems - "situations start to be defined as problems and increase their chances of becoming a priority in agenda, when we believe that we must do something to change them" (KINGDON, 2006b, p. 227). Regarding the means, the author highlights three aspects. a) indicators (measures that reveal the magnitude of a situation and the changes it undergoes); b) focus events (crises, symbols and other events that call attention to some situations more than others); and c) feedback from governmental actions (they can be formal, such as cost monitoring or program evaluation, or informal, such as articles in the press). Considering problems as social constructs, the way in which a situation is defined as a problem depends on how the means are interpreted. In addition, analyzing it can reveal trends such as a threat to important values, undesirable disparities in comparison with other countries / regions, or a categorization that draws more attention than others do. Describing a situation as a problem is strategically important for the addition of an issue on the agenda.

In turn, the stream of solutions or public policies refers to a set of alternatives for solving problems. Kingdon considers that ideas generated in this stream can be unrelated to the perception of specific problems. Consequently, the issues on the governmental agenda not necessarily characterize a marriage between problems and solutions. As noted by Capella (2007),

${ }^{2}$ About the garbage can model (MARCH, OLSEN and COHEN, 1972), Souza (2006, p. 31) summarizes: "the model advocates that solutions look for problems. The choices make up a garbage can in which various types of problems and solutions are posed by the participants as they appear". 
the author attributes a crucial role to ideas in his model, arguing that they are often more important for choosing an alternative than the influence pressure groups may make.

Inspired by the biological process of natural selection, Kingdon (1995) names the process in which numerous ideas are formulated and confronted by policy communities (groups of governmental and non-governmental experts) policy primeval soup (the primitive broth of policies). Only a few survive this process and satisfy the generally established criteria of technical feasibility, acceptance and consensus strength (VIANA, 1996, p. 9). In this sense, Kingdon (2006b, p. 232) argues that "the evaluation of proposals, in part, takes into account political support or opposition, but it is also, on the other hand, based on logical and analytical criteria". He adds that the alternatives chosen need to be disseminated with persuasion in different forums, "in a long softening process" in which rework is more important than transformation.

The same author states that the political stream flows according to its own dynamics and rules, being negotiation rather than persuasion the source of consensus (KINGDON, 2006b). Three elements affect this stream: a) national mood (or national climate) is the perception of the decision-making process expressed by social movements, media and others. It points whether society is favorable towards certain issues or not; b) organized forces - they are the interest groups that either support or try to obstruct an issue being added into the agenda. They are those who may increase political costs for possible choices; and c) turnover (changes in government) that may result from an electoral process or internally from the government, involving people in a strategic position, such as ministers and high-ranking officials, changes in the composition of the National Congress or changes in competence over certain issues. According to Kingdon, in the political stream, national mood and turnover are the factors that influence most the setting of governmental agenda or its adjustments (CAPELLA, 2007).

Despite the independence of these three streams, changes in agenda depend on their convergence, catalyzed by entrepreneurial performance. Kingdon names the circumstances that make this convergence possible as "windows of opportunity". According to the author, "a complete link combines the three dynamics - problems, public policies and politics - in a single package" (KINGDON, 2006b, p. 234): it is the moment when a problem is recognized, a solution is available and the political conditions are favorable. This convergence allows issues to be put on the decision agenda (CAPELLA, 2016). The windows in question open up either on the streams of the problem or politics and provide the institutional context, restrictions and opportunities to create public policies (JONES, PETERSON, PIERCE et al., 2006).

Regarding streams, Kingdon (1995) creates a typology for actors according to their different contributions. Starting with policy entrepreneurs, they are key players in identifying windows of opportunity and making the convergence of streams feasible. Capella $(2007$, p. 97) notes that "they play a fundamental role, uniting solutions to problems; proposals to political moments; political events to problems". For the author, entrepreneurs are individuals or small groups of people who advocate for ideas and are able to find the right moment to connect them to problems and solutions. These entrepreneurs invest their resources (time, energy, reputation and financial resources) to reap benefits that can be material gains, the promotion of values and ideologies or the simple pleasure of taking part in the game. Their success depends on three critical factors, synthesized by Jones, Peterson, Pierce et al. (2016): resources, access to decision-makers and strategy.

Concerning actors, it is important to distinguish visible participants, those who receive the most attention from the public (president, senior advisers, members of the National Congress, media and political parties), and invisible participants, specialists who make up policy communities (bureaucrats career, academics, researchers and analysts working for interest groups). Kingdon (2006b, p. 230, emphasis added) makes the following digression: "the group of visible actors sets the agenda while the group of invisible actors has greater power influence on the choice of alternatives". This demonstrates the topdown character of choosing subjects and the importance of intersectoriality in specifying alternatives. Kingdon highlighted that the top of the executive branch is the most influential visible actor for shaping the agenda; the media would be the least relevant because it is usually only interested in transmitting issues to the public after the agenda was set; and interest groups would have an obstructive performance, but never strong enough for an issue to be added to the agenda solely for their action (CAPELLA, 2007). 
Although MSM has emerged as a major advance in the field of public policy, it is not exempt from criticism. Sabatier's (2007) and Mucciaroni's (1992) stand out. Sabatier (2007) points out that the hypothesis that the streams are independent cannot be falsified, because Kingdon does not make it clear how to identify actors and / or tasks present in each stream. The author also claims that there is no specification to causal motives because Kingdon does not offer a clear model of individual action. Mucciaroni (1992), on the other hand, considers MSM extremely descriptive and endowed with low predictive power. It would only adapt to fragmented institutional structures, based on pluralist participation and temporary coalitions. Therefore, its explanatory potential would be reduced depending on the political system. Mucciaroni (1992) also questions the independence of the flows and suggests that changes in one causes subsequent changes in the others, making convergence less fortuitous and the process intentional and strategic.

In short, unlike rationalist approaches to policymaking, Kingdon's framework is based on ambiguous conditions. This means that it leaves room for more than just one interpretation of a phenomenon or an issue. Ambiguity promotes innovation and MSM provides analytical tools to explain how and under which conditions political systems and organizations make sense in their context (ZAHARIADIS, 2007).

\section{The National Strategy for Financial Education - from international developments and national context to the master plan elaboration}

In the beginning of the year 2000, the strong correlation between poverty and financial exclusion shed light on the international debate about economic development, culminating in the definition of the G20 Principles for Innovative Financial Inclusion. The fifth of these nine principles states that member countries must promote financial education and training (GPFI, 2010).

Although the G20 Principles were only established in 2010, OECD had already been engaged in the issue of financial education since 2003, when it established the "Financial Education Project" (OECD, 2004). Based on questionnaires, the project team surveyed the state of the art of financial education in member countries, subsequently elaborating an extensive publication (OECD, 2005b) that presented classification and evaluation of existing programs. This project also resulted in a document called Recommendation on principles and good practices for financial education and awareness (OECD 2005a), in which the OECD council invited member and non-member countries to consider their recommendations and disseminate the principles and good practices amongst institutions in the public and private sectors, profit or nonprofit, that were involved in the subject. This same document served as a basis for the definition adopted by Brazil in its master plan (ENEF, 2010a, p. 20):

Financial education is the process by which individuals and societies improve their understanding of financial concepts and products, so that, with clear information, training and guidance, they acquire the necessary values and skills to become aware of opportunities and risks comprised in them, and then make informed choices, know where to look for help, take other actions that improve their well-being, thus contributing consistently to the formation of responsible individuals and societies, committed to the future.

In 2008, the OECD launched a network, the International Network for Financial Education (INFE), to promote and facilitate international cooperation, allowing the participation of non-member countries.

According to the OECD, it has become easier to access financial services and the sophistication and complexity of the nowavailable instruments transferred some of their inherent risks to individuals. Therefore, financial education has become a valuable complement to financial inclusion and consumer protection, as well as for restoring confidence in financial markets and contributing to financial stability (OECD, 2015).

Brazil experienced important transformations that increased consumer demand for financial products and services simultaneously with this trend in international forums. From 2002 until the deepening of the country's economic crisis in 2015, the Brazilian socio-economic pyramid underwent a noticeable change in its base. Social programs, macroeconomic 
stability, growth in gross domestic product (GDP), real increases in the minimum wage and increase in formal employment were the main determinants of the income mobility experienced by the less favored population. This led to the prominence of the "new class C".

According to Neri and Carvalhaes (2008), the Gini index that measures income inequality decreased from 0.6068 in 1993 to 0.5546 in 2007, while extreme poverty decreased more than $58 \%$ in the same period. Based on data from the National Household Sample Survey of the Brazilian Institute of Geography and Statistics (PNAD/IBGE), the authors state that $47 \%$ of the Brazilian population in 2007 were the new class C compared to 31\% in 1993.

Thus, financial inclusion gained importance in Brazil under the influence of international recommendations and due to pressure from the new socioeconomic and demographic context. This new reality and the increasing sophistication of the financial system require individuals to be prepared to make harmless choices to them.

In 2007, the Committee for Regulation and Inspection of the Financial, Capital, Insurance, Pension Plans and Capitalization Markets (Coremec) decided to establish a working group (WG) to outline a strategy of scope for financial education. The idea was to gather government representatives, private sector and civil society to build a legitimate proposal and commit to its execution.

Coremec was created in 2006 to coordinate and improve the performance of federal agencies in charge of management and control of activities related to the financial system and public funding of popular savings. Were Committee members the president of the Central Bank of Brazil (BCB) and a director of that autarchy, the president of the Brazilian Securities and Exchange Commission (CVM) and a director of that autarchy, the Secretary of Complementary Pension (of the former Secretariat of Complementary Pension [SPC] , subsequently the National Superintendency of Complementary Welfare [PREVIC]), the Ministry of Social Security and a director of that secretariat, and the Superintendent of the Superintendence of Private Insurance (SUSEP) and a director of that superintendence. Its functions were a) propose the adoption of measures that aim at the correct functioning of the financial and capital markets; b) discuss regulatory and supervisory initiatives that can harmonize the activities of its members; and c) facilitate and coordinate the exchange of information between its members and international organizations. The members of the WG were employees appointed by each of the aforementioned agencies and the CVM was responsible for its coordination.

\section{The preparation studies for formulation of the National Strategy for Financial Education ${ }_{3}$}

To assess the country's main financial education needs, the WG considered three sources of information as a starting point: a) a national survey; b) experiences from other countries; and c) the survey of financial education initiatives coexisting in the country.

In 2008, the WG carried out a national survey with the purpose of measuring the population's degree of financial education. With different income profiles and educational levels, 1,809 people were interviewed in six capitals - Porto Alegre, Salvador, Brasília, São Paulo, Recife and Rio de Janeiro. The results showed that people do not plan their spending in the long term, they do not take time to prepare financially for retirement, they are not aware of the risks offered by financial instruments, nor of the resources for their protection, they have difficulties in making decisions regarding loans and investments and they are vulnerable to fraud.

The WG's analyses of international experiences found that countries like the USA, the United Kingdom, Spain, Australia and New Zealand recognize the need to educate citizens financially because they acknowledge the increasing complexity and variety of financial products, the increase in life expectancy and the relevant changes in income composition and distribution. These countries' governments, private-sector entities and civil societies were involved in the launch of initiatives to reach different audiences (children, adults, families, communities etc.). In some cases, marketing efforts and education got confused.

\footnotetext{
3 This sub-item was prepared based on the ENEF master plan and on the document "Brazil: Implementing the National Strategy", which is part of the study Advancing national strategies for financial education (OECD and G20, 2013).
} 
Regarding the mapping of existing financial education initiatives in the country, it identified governmental actions and carried out a "call" over the internet, applying the criteria of gratuity and prevalence of public interest to exclude programs with potential conflicts of interest. Several single and uncoordinated initiatives from the financial sector and non-governmental organizations (NGOs) were also found. This survey resulted in a selection of nine subjects to be researched further: financial planning; economy; financial services; credit and interest; investments; social security; insurance; capitalization; and, consumer protection and defense. The first steps to formulate ENEF yet within the scope of the WG had these subjects as a subsidy for the development of a content matrix and an action plan to guide the financial education of young people and adults.

Additionally, the WG mapped stakeholders, identifying actors who were related to the final recipients of the policy. Some examples are representatives of public educational institutions at the federal, state and municipal levels; public institutions linked to the nine themes mentioned above; and private institutions within the jurisdiction of each of the regulators - financial, capital, insurance, pension plan and capitalization markets.

The following stage consisted in making these stakeholders assisting members of the WG. It was a necessary move given that it would be impracticable to plan and execute a national financial education strategy with the sole support of government agencies and Coremec parties. Finally the WG had representatives from the Ministry of Finance, the Ministry of Education, the Ministry of Justice and the Ministry of Social Security, the National Council of Secretaries of Education (CONSED), the National Union of Municipal Directors of Education (UNDIME), state education secretariats, the Stock and Futures Exchange (at the time called BM\&FBovespa), the Brazilian Federation of Banks (Febraban), the Brazilian Association of Financial and Capital Market Entities (Anbima) and the National Confederation of General Insurance Companies, Social Security And Life, Supplementary Health and Capitalization (CNSeg). Specialists in pedagogy, economic psychology, didactics and communication were also consulted to contribute with guidelines for Early Childhood Education, Elementary Education and High School.

\section{The master plan of the National Strategy for Financial Education}

The outline of ENEF in the form of a master plan was the result of the work carried out by the WG together with the stakeholders. The master plan contained descriptions of scenarios, challenges and guidelines to help with the formulation of content and actions, and a governance proposal.

The official creation of ENEF was based on this master plan, whose objectives were: a) to promote financial and social security education; $b$ ) increase the citizen's ability to make conscious choices about the management of their resources; and c) contribute to the efficiency and strength of the financial, capital, insurance, pension and capitalization markets. Thereby:

The National Strategy for Financial Education - ENEF - is a multisectoral mobilization around the promotion of financial education actions in Brazil. The strategy was instituted as a permanent State policy, and its main characteristics are the guarantee of free initiatives that it develops or supports and its commercial impartiality. The purpose of ENEF, created through Federal Decree 7,397/2010, is to contribute to the strengthening of citizenship by providing and supporting actions that help the population to make more autonomous and conscious financial decisions (ENEF, 2017).

ENEF's actions are composed of transversal and sectorial programs, which centralize coordination and decentralized execution. The cross-cutting initiatives include multidisciplinary programs with national reach, requiring the articulation of several government sectors, private institutions and civil society for their formulation and implementation. They are divided into two groups: financial education in schools, for children and young people; and financial education for adults. Additionally, sectorial initiatives refer to actions by public or private entities with specific objectives and target audiences, developed independently, but integrated with ENEF based on the recognition of their adherence to the objectives of the master plan.

To make the project economically and financially viable and enable its implementation, the master plan suggested the maintenance of the articulation between the various levels of government and the private initiative. The National Committee for Financial Education (CONEF) ${ }_{4}$ would be the centralized figure to coordinate it and a governance structure that institutionalized partnerships with the private sector, originated in the context of the WG, would be responsible for its decentralized execution.

${ }^{4}$ CONEF was conceived as an entity responsible for the direction, supervision and promotion of ENEF, comprised by seven government bodies and entities and six civil society organizations. 


\section{The multiple streams model applied to the Brazilian National Strategy for Financial Education}

Based on the theoretical framework of MSM, the contextualization and description of the pre-decision stages of ENEF in the previous sections, one can identify the trajectory of financial education through the different levels of the agenda. Further, one can explore the processes of recognizing the problem (problem stream), specifying alternatives to it (public policy stream) and the political environment (political stream) that culminated in the window of opportunity for the insertion of financial education in the decision agenda. Initially, it can be inferred that successive OECD actions were largely responsible for insertion of the topic on the systemic agenda. Take the case of the organization's effort to draw the attention of member and non-member countries to the importance of financial education in the context of development and well-being, consumer protection and stability of the financial system. The OECD is an influential institution in international forums and one that Brazil has been approaching since 2000, by observing or participating in several committees. According to information available on the Ministry of Finance's website (2019), in May 2007, the OECD Ministerial Council decided to strengthen cooperation with Brazil, China, India, Indonesia and South Africa in a program of enhanced engagement, foreseeing a possibility of acceptance of these countries as members.

Three other factors indicate the presence of financial education on the Brazilian systemic agenda: a) the increasing complexity of the financial system and the vulnerability of individuals to crises, which can be considered as focus events; b) the expansion of the financial inclusion of the less favored population as a result of the social changes experienced by the country, which would be indicators; and c) the adoption of partial solutions with uncoordinated financial education initiatives by private sector actors and some government agencies, characterizing feedback.

\section{The problem stream}

The insertion of the topic on the governmental agenda occurs when Coremec institutes the WG and designates its employees to survey Brazilian population's level of financial education, research about international experiences and national and international initiatives and then propose a nationwide strategy. WG members thus assume the role of invisible actors.

Although there is no evidence of where this Coremec decision came from, the context allows us to infer that it was a natural path. Take the case of the financial inclusion efforts undertaken for some years, such as the regulation of banking correspondents by the $\mathrm{BCB}$ and incentive programs for microcredit. It is likely that visible actors close to the presidency have understood financial education as a complementary need for the success of the most comprehensive project of financial inclusion and empowerment of the new class $\mathrm{C}$. The visible actors were not only responsible for governmental guidelines in the economic area, but were also aware of the previous inclusion efforts and interpreted the indicators from socioeconomic policies. An additional factor is that, aspiring to achieve the position of member country, these same actors may have seen ENEF as an opportunity to increase Brazilian visibility to the OECD. The WG then builds a more holistic view of the situation, starting to define it as a problem. Applying Kingdon's concepts (2006b), this process takes place by comparison with other countries that had already started their national financial education strategies. Also, the survey findings pointed to a threat to important values, as they revealed that, despite the increased income, the population profile continued to be more likely to spend than to save, resulting in high levels of indebtedness, default and unpreparedness for retirement. The characterization of the problem became even more evident from a new focus event: the 2008 global financial crisis and its consequences.

\section{The public policy stream}

In parallel to the studies, the WG also analyzed specifying alternatives. With the involvement of other sectors of the government, specialists in educational issues and actors from the private sector, who, from Kingdon's perspective can be identified as policy communities, the policy primeval soup process took place marking the stream of public policy. The proposal of a networked governance structure with centralized coordination, respecting the transversality of the subject and the intersectoral nature of the execution, were key factors in meeting the technical feasibility standards and budgetary flexibility of the project. These characteristics increased its chances of choice because they indicate strong adherence to the logical-analytical criteria, to technical feasibility, acceptance and strength of consensus highlighted by Viana (1996) and Kingdon (2006b). 


\section{The political stream}

Among the three influential elements in the political stream pointed out by Kingdon (2006b), national mood is the most prominent in the case of ENEF. Strong social content in the agenda characterize the eight years of Lula's government. At the end of his second term, the election of a party's successor shows a favorable national mood as well as the level of approval in pools regarding adopted policies express popular support. The prevailing political climate in December 2010, when the presidential decree that instituted ENEF was signed, it proved to be highly conducive to measures meant to empower the less privileged sections of the population.

On the other hand, it is ruled out that the rise of ENEF to the decision agenda was due to what Kingdon (2006b) conceptualizes as a turnover, given that the signing of the decree occurred at the end of the presidential term. It would then remain the possibility of having been motivated by the imminence of the turnover, which would jeopardize the project's continuity due to the change of government. However, this hypothesis is also unlikely, since the president-elect committed herself to follow a similar path to her predecessor's, which includes the maintenance of cadres like ministers Guido Mantega and Fernando Haddad (Finance and Education, respectively), whose teams were involved in this project.

Regarding the performance of organized forces, Martins (2013) points out that there was a rise to an imbalance of interests. There was a predominance of business representatives from the financial system along with the absence of representatives of civil society and consumer rights defenders as auxiliary members invited to constitute the WG. Financial service providers monopolized a communication channel that should have been shared with the population that are the final consumes of such services, which is precisely the target audience of ENEF. The inclusion of representatives from institutions such as the Brazilian Institute for Consumer Protection (IDEC) would have reduced this asymmetry. Despite the influence of the private sector in the content of the master plan, its persuasion to open the political window is less evident than that exercised by the national mood.

\section{The window of opportunity and the convergence offlows}

Throughout the work of the WG, the problem recognition was drawn, and, in parallel, the invisible actors and the policy communities tied up alternative solutions. Together they formed a master plan. In 2009, when Coremec received the proposal, the agency decided to create a new WG, this turn under the coordination of SUSEP, with the purpose of coordinating the necessary acts for the institution of ENEF. One of them was to hold a restricted hearing to gather suggestions for changes to the proposal, to evaluate possibilities of partnership for the execution of programs and to write the normative act (COREMEC, 2009). At the end of 2010, when the WG assignment was concluded and the public policy proposal was ready, the traumas of the 2008 international financial crisis still reverberated as a warning. In addition, the $\mathbf{G} 20$ had announced at the time, in a May 2010 meeting, the Principles for Innovative Financial Inclusion (GPFI, 2010), featuring a problem window. On the same occasion, the political scenario was favorable, due to the end of a mandate guided by the national mood - which was favorable to inclusion policies -, and the new government's promise of continuity, configuring a policy window. According to Martins (2013, p. 72), ENEF's proposal:

[...] appears in a context characterized, on the one hand, by an association of positive indicators in the domestic economy, such as the historical growth of the credit portfolio; the vigorous economic activity in the period from 2005 to 2008; the robustness of the labor market and the unprecedented growth of the new middle class and, on the other hand, by a strong international financial crisis, by the increasing rates of defaults and indebtedness of families. It is possible to identify this context in light of Kingdon's window of opportunity.

For Kingdon (2006b, p. 236), "an open window for public policies constitutes an opportunity for the defenders of a given cause to offer their solutions, or to draw attention to problems that they consider special", a role that, in this case, was played by Coremec. The committee proved to be endowed with the factors listed by Jones, Peterson, Pierce et al. (2016) as essential for the success of policy entrepreneurs: available resources; access to decision-makers; and strategic sense. This small group of people was formed by the top directors of the financial system's regulatory agencies and had highly qualified employees at their disposal to carry out studies and design alternatives. They had direct access to at least one visible actor linked to the presidency - the minister of Finance - and, after three years of work, they correctly identified the window of opportunity.

Another factor that confirms Coremec's role as an entrepreneur is the promotion of intersectoriality in the pre-decision stages, by allowing the participation of external auxiliary members in the WG. The performance of representatives of different 
ministries and private sector entities contributed to neutralize any interest groups that could act as forces against the rise of ENEF, because, as all of them were participating in the formulation and choice of alternatives, they would have no arguments to oppose to the final result.

The convergence of flows raised ENEF to the government's decision agenda. The pre-decision stages end with the Decree no. 7,397, on December 22, 2010 (BRASIL, 2010), which formalized the structure of governance that aims at the continuous formulation, implementation and evaluation of the new permanent and national public policy.

\section{CONCLUSION}

This article is placed on the field of studies of agenda-setting in public policies. It relies on Kingdon's theoretical framework $(1995,2006 a, 2006 b)$ to support a case study about the paths that led to the launch of a national strategy of financial education in Brazil, the so-called ENEF.

The OECD and other international forums recommend the adoption of national strategies to prepare individuals for making conscious decisions regarding their finances. These organizations believe financial education is a fundamental condition for the population's well-being and socioeconomic development. In a country like Brazil, the urge to implement such policies disputes attention with many other social and economic priorities. Therefore, in this article we sought to identify two processes: what led to the conviction that a financial education strategy should be in the governmental agenda; and how were the solutions sewn up to the adoption of a public policy.

This case study suggests that the OECD's influence, since 2003, was not enough to draw immediate attention from the Brazilian government to financial education. The right conditions were built over time. Some of them are a more detailed perception of the national context and the natural developments towards a greater objective (financial inclusion), which were followed by the effects of unexpected events (2008 global financial crisis) and the comparison between the national situation and other countries'. Should the situation not have been defined as problem, financial education would not have been stressed as a priority on the agenda. Financial education only turned into public policy because the project was perceived as viable and efforts were made towards communicating it effectively, by presenting a master plan in a favorable political context.

When Kingdon's theoretical elements $(1995,2006 a, 2006 b)$ were applied in this studied case, they shed light on the importance of converging three elements - problem identification, available solutions and the political context - for the project to achieve approval. Considering that this article empirically demonstrates that prefabricated solutions are not enough for a subject to be added in the governmental agenda, this piece contributes to the understanding of this specific study case and general decision-making processes within the State. Therefore, it may be useful to improve the conduction of pre-decision stages in new projects. Another point of emphasis in the article is the sui generis character of the policy in question: its theme is unconventional and its shared responsibility between the private and public sectors is atypical. For these reasons and because ENEF has a complex structure of network and governance, it is suggested that future studies on the topic address the challenges faced in its formulation and implementation.

\section{ACKNOWLEDGEMENTS}

This study was financed in part by the Coordenação de Aperfeiçoamento de Pessoal de Ensino Superior - Brasil (CAPES) Finance code 001. 


\section{REFERENCES}

BAUMGARTNER, F.; JONES, B. Agendas and instability in American politics. Chicago: University of Chicago Press, 1993.

BRASIL. Decreto n. 7.397, de 22 de dezembro de 2010. 2010. Available at: <http://www.planalto.gov.br/ccivil_03/_Ato2007-2010/2010/ Decreto/D7397.htm>. Accessed on: Mar. 25, 2019.

CAPELLA, A. C. N. Perspectivas teóricas sobre o processo de formulação de políticas públicas. In: HOCHMAN, G.; ARRETCHE, M.; MARQUES, E. (Orgs.). Políticas públicas no Brasil. Rio de Janeiro: Ed. Fiocruz, 2007. p. 87-122.

CAPELLA, A. C. N. A trajetória das políticas de administração pública na agenda governamental: os governos FHC e Lula. Temas em Administração, v. 2, n. 2, p. 1-14, 2008.

CAPELLA, A. C. N. Um estudo sobre o conceito de empreendedor de políticas públicas: ideias, interesses e mudanças. Cadernos EBAPE. BR, Rio de Janeiro, v. 14, ed. esp., p. 486-505, 2016.

COMITÊ DE REGULAÇÃO E FISCALIZAÇÃO DOS MERCADOS FINANCEIRO, DE CAPITAIS, DE SEGUROS, DE PREVIDÊNCIA E CAPITALIZAÇÃO COREMEC. Deliberação Coremec n. 8, de 19 de junho de 2009. 2009. Available at: <http://www.previc.gov.br/regulacao/normas/ deliberacoes/coremec/deliberacao-coremec-no-8-de-19-dejunho-de-2009.pdf/view>. Accessed on: Jan 14, 2020.

ESTRATÉGIA NACIONAL DE EDUCAÇÃO FINANCEIRA - ENEF. Quem somos. 2017. Available at: <http://www.vidaedinheiro.gov.br/ quemsomos/>. Accessed on: 22 mar. 2019.

ESTRATÉGIA NACIONAL DE EDUCAÇÃO FINANCEIRA - ENEF. Plano Diretor. 2010a. Available at: <http://www.vidaedinheiro.gov.br/ wp-content/uploads/2017/08/Plano-Diretor-ENEF-EstrategiaNacional-de-Educacao-Financeira.pdf>. Accessed on: Mar. 26, 2019.

ESTRATÉGIA NACIONAL DE EDUCAÇÃO FINANCEIRA - ENEF. Anexos ao Plano Diretor. 2010b. Available at: <http://www.vidaedinheiro. gov.br/wp-content/uploads/2017/08/Plano-Diretor-ENEF-anexosATUALIZADO_compressed.pdf>. Accessed on: Mar. 26, 2019.

GLOBAL PARTNERSHIP FOR FINANCIAL INCLUSION - GPFI. G-20 Principles and Report on Innovative Financial Inclusion. 2010. Available at: <https://www.gpfi.org/sites/gpfi/files/documents/ Principles\%20and\%20Report\%20on\%20Innovative\%20Financial\%20 Inclusion_0.pdf>. Accessed on: Aug. 18, 2019.

JONES, M. D. et al. A river runs through it: a multiple streams metareview. Policy Studies Journal, v. 44, n. 1, p. 13-36, 2016.

KINGDON, J. W. Agendas, alternatives and public policies. 2. ed. New York: Harper Collins, 1995.

KINGDON, J. W. Como chega a hora de uma ideia? In: SARAVIA, E.; FERRAREZI, E. (Orgs.). Políticas públicas: coletânea. Brasília, DF: Escola Nacional de Administração Pública, 2006a. p. 219-224.

KINGDON, J. W. Juntando as coisas. In: SARAVIA, E.; FERRAREZI, E. (Org.). Políticas públicas: coletânea. Brasília, DF: Escola Nacional de Administração Pública, 2006b. p. 225-245.

MARCH, J. G.; OLSEN, J. P.; COHEN, M. D. A garbage can model of organizational choice. Administrative Science Quartely, v. 17, p. 1-25, 1972.
MARTINS, A. Q. N. A formação da Estratégia Nacional de Educação Financeira do governo brasileiro. Rio de Janeiro: Escola Nacional de Saúde Pública Sergio Arouca, 2013.

MINISTÉRIO DA FAZENDA. Organização para a Cooperação e Desenvolvimento Econômico - OCDE. 2019. Available at: <http:// www.fazenda.gov.br/assuntos/atuacao-internacional/cooperacaointernacional/ocde>. Accessed on: Mar. 21, 2019.

MUCCIARONI, G. The garbage can model and the study of policy making: a critique. Polity, v. 24, p. 459-482, 1992.

NAGEM F. A.; SILVA, S. P. Institucionalização e execução das políticas públicas de economia solidária no Brasil. Revista de Sociologia e Política, v. 21, n. 46, p. 159-175, 2013

NERI, M. C., CARVALHAES, L. Miséria e a nova classe média na década da igualdade. Rio de Janeiro: FGV/IBRE, 2008.

ORGANISATION FOR ECONOMIC CO-OPERATION AND DEVELOPMENT - OECD. OECD's Financial Education Project. 2004. Available at: <https://www.oecd.org/finance/financial-education/33865427.pdf>. Accessed on: Mar. 10, 2019.

ORGANISATION FOR ECONOMIC CO-OPERATION AND DEVELOPMENT - OECD. Recommendation on principles and good practices for financial education and awareness. 2005a. Available at: <http:// www.oecd.org/daf/fin/financial-education/35108560.pdf>. Accessed on: Mar. 26, 2019.

ORGANISATION FOR ECONOMIC CO-OPERATION AND DEVELOPMENT - OECD. Improving financial literacy: analysis of issues and policies. 2005b. Available at: <https://read.oecd-ilibrary.org/finance-andinvestment/improving-financial-literacy_9789264012578-en>. Accessed on: Mar. 26, 2019.

ORGANISATION FOR ECONOMIC CO-OPERATION AND DEVELOPMENT - OECD; GROUP OF TWENTY - G20. Advancing national strategies for financial education. 2013. Available at: <https://www.oecd.org/ finance/financial-education/G20_OECD_NSFinancialEducation.pdf $>$. Accessed on: Mar. 26, 2019.

ORGANISATION FOR ECONOMIC CO-OPERATION AND DEVELOPMENT - OECD. Highlights on national strategies for financial education policy handbook. 2015. Available at: <https://www.oecd.org/daf/fin/ financial-education/National-Strategies-Financial-Education-PolicyHandbook-Highlights.pdf>. Accessed on: Mar. 26, 2019.

PEREIRA, M. C. G.; TEIXEIRA, M. A. C. A inclusão de catadores em programas de coleta seletiva: da agenda local à nacional. Cadernos EBAPE.BR, Rio de Janeiro, v. 9, n. 3, p. 895-913, 2011

PINTO, I. C. M. Construção da agenda governamental: atores, arenas e processo decisório na saúde. Organizações \& Sociedade, v. 15, n. 44, p. 13-23, 2008.

SABATIER, P. A. Fostering the development of policy theory. In: SABATIER, P. A. (Ed.). Theories of the policy process. Cambridge: Westview Press, 2007. p. 321-336.

SOUZA, C. Políticas públicas: uma revisão da literatura. Sociologias, v. 8, n. 16 , p. 29-35, 2006. 
VIANA, A. L. Abordagens metodológicas em políticas públicas. Revista de Administração Pública, Rio de Janeiro, v. 30, n. 2, p. 5-43, 1996.
ZAHARIADIS, N. The multiple streams framework: structure, limitations, prospects. In: SABATIER, P. A. (Ed.). Theories of the policy process. Cambridge: Westview Press, 2007. p. 65-92. 